\title{
Acadian transpression and the exhumation of the sillimanite- bearing Passagassawakeag terrane along the Liberty-Orrington Fault, coastal Maine
}

\author{
Heather Short* \\ Department of Earth and Atmospheric Sciences, University at Albany (SUNY), \\ 1400 Washington Avenue, Albany, New York12222<ha_short@yahoo.com> \\ *Current address: $402 \mathrm{~A}$ Hewitt Rd. Bristol, Vermont 05443
}

Date Received: January 27, 2000

Date Accepted: September 29, 2000

\begin{abstract}
New detailed mapping in central coastal Maine shows the existence of a dextral strike-slip mylonitic shear zone, 250$500 \mathrm{~m}$ thick, separating the sillimanite-grade Passagassawakeag terrane and the chlorite-grade Bucksport Formation of the Fredericton Trough. Foliation within the shear zone is near-vertical, with near-horizontal stretching lineations and pervasive dextral sense-of-shear indicators. Followed eastward, this northeast-striking terrane boundary turns north. A thin unit of aiternating layers of quartz and garnet+biotite+magnetite, previously interpreted as the stratigraphic Rider Bluff unit, lies along this north-south striking (eastern) part of the Passagassawakeag-Bucksport boundary. Petrographic analysis demonstrates that the layering in this unit is a tectonic fabric, and the entire unit is interpreted as consisting of mylonites formed along a transpressional thrust, now overturned, along which the Passagassawakeag terrane was exhumed. If this is the case, the Liberty-Orrington shear zone may represent part of an orogen-scale dextral shear zone, continuous with the Penobscot Bay and Norumbega fault zones, through the Acadian orogeny.
\end{abstract}

De nouveaux travaux de cartographie détaillés du centre du littoral du Maine révèlent l'existence d'une zone cisaillée mylonitique à décrochement dextre de 250 à 500 mètres d'épaisseur séparant le terrane à sillimanite de Passagassawakeag et la Formation à chlorite de Bucksport de la dépression de Fredericton. La zone cisaillée présente une schistosité presque verticale, avec des linéations quasi-horizontales qui s'étirent et des indicateurs d'une orientation dextre pénétrante du cisaillement. Vers l'est, la limite de ce terrane orienté vers le nord-est tourne vers le nord. Une unité mince de strates alternantes de quartz et de grenat+biotite+magnétite, auparavant interprétée comme l'unité stratigraphique de Rider Bluff, longe cette partie (orientale) à orientation nord-sud de la ligne de démarcation entre Passagassawakeag et Bucksport. Une analyse pétrographique révèle que la stratification à l'intérieur de cette unité est de fabrique tectonique; on interprète l'ensemble de l'unité comme une unité constituée de mylonites s'étant formée le long d'un chevauchement transpressionnel, maintenant renversé, le long duquel le terrane de Passagassawakeag a été exhumé. Si c'est bien le cas, la zone de cisaillement de Liberty-Orrington pourrait représenter une partie d'une zone de cisaillement dextre orogénique maintenant une continuité avec les zones faillées de la baie de Penobscot et de Norumbega pendant l'orogenèse acadienne.

Traduit par la rédaction

\section{INTRODUCTION}

In the Early Paleozoic, the eastern margin (present coordinates) of Laurentia experienced a series of tectonic events resulting in the accretion of island arcs, back-arc basins, composite terranes, and microcontinents, known as the Appalachian Orogen. The temporal and spatial distribution of the tectonic events varies throughout eastern North America, but has been generally divided into three distinct orogenies: the Taconic (mid-late Ordovician), the Acadian (Devonian), and the Alleghanian (Carboniferous). In recent years, this tendency to 'fit' metamorphic, igneous, and structural events into specific orogens has been shown to be an oversimplification of actual events (Stewart et al. 1995a; van Staal and de Roo 1995). Detailed, multidisciplinary studies in the northeastern United States and Maritime Canada have determined that several outboard composite terranes were amalgamated prior to accretion to Laurentia or Gondwana, adding Penobscot and Salinic to the list of early Paleozoic orogenies (Stewart et al. 1995a; Boone and Boudette 1989; West et al. 1992). In light of this, some workers envision the Appalachian Orogen in the northeast as a continuous convergence, punctuated by collisions and accretion of various terranes, the stages of which are defined by tectonic style (van Staal and de Roo 1995). In this paper, the term 'Acadian orogeny' is used to refer to the period of time when the outboard Gondwanan terranes of coastal Maine are considered to have accreted to Laurentia, including the resultant regional metamorphism and deformation. This is generally thought to have occurred from the Late Silurian to the Late Devonian in coastal Maine.

The application of terrane analysis to coastal Maine and the Acadian orogeny at large is not new nor is the concept of major strike-slip faults generated by oblique collision (Zen 1983). However, the importance of orogen-scale strike-slip faults as the primary means for the exhumation and 


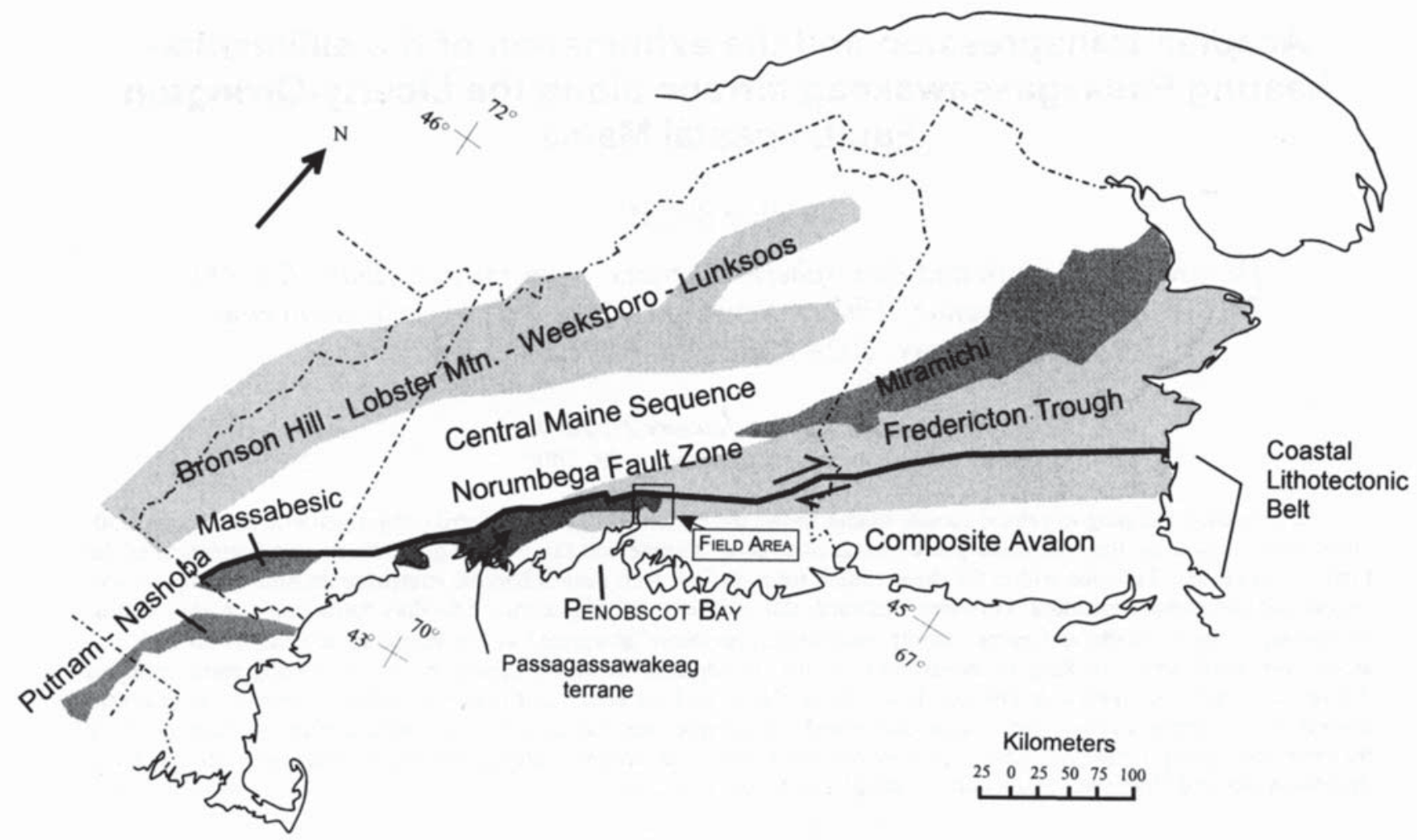

Fig. 1. Regional tectonic map showing location of Bucksport-Orland field area, Fredericton Trough, and Passagassawakeag terrane. Adapted from Rast and Skehan (1993).

amalgamation of lithotectonic terranes in coastal Maine has not been fully realized. Transpressional tectonics have long been recognized in other portions of the Appalachians and equivalents in the Canadian Maritimes, Newfoundland, Scandinavia, and the British Isles (Doig et al. 1990; Piasecki 1995; van Staal et al. 1998; Stewart et al. 1995a and 1995b; van Staal and de Roo 1995; and many others). A general sequence of deformation styles has been proposed for the Acadian orogeny in Maritime Canada, and involves early collisional thrusts and folds with some sinistral motion followed by extensional collapse and a transition to widespread dextral strike-slip faulting (Malo and Kirkwood 1995; van Staal and de Roo 1995).

\section{GEOLOGICAL SETTING}

The Bucksport-Orland study area lies within the Coastal Lithotectonic Belt (CLTB) of east-central Maine, a significant but poorly understood component of the Northern Appalachian Orogenic Belt (Fig. 1). The CLTB consists of seven lithotectonic terranes, each with differing pre-Acadian histories, separated by what are generally believed to be thrust faults (Osberg et al. 1985). The geologic histories of these terranes are complex, and their full description is outside the scope of this paper. All terranes are thought to have undergone several episodes of mid- to late Devonian regional metamorphism and deformation associated with the Acadian orogeny (Osberg et al. 1989), although recent workers have documented Silurian metamorphism in western Penobscot Bay (e.g. West et al. 1995). Two of these terranes, the sillimanitebearing gneisses of the Passagassawakeag terrane (Orrington-
Liberty belt of Stewart et al. 1995) and the chlorite-to-biotite grade turbidites of the Bucksport Formation of the Fredericton Trough (Ludman 1986) are present within the study area. They are separated by the Liberty-Orrington Fault (Long Lake Fault of Stewart and Wones 1974), which is intruded by the Devonian (371 $\pm 2 \mathrm{Ma}$; Tucker et al. 1998) Mt. Waldo granite just southwest of the study area, and is very near the contact aureole of the Lucerne granite $(412 \pm 12 \mathrm{Ma}$; Zartman and Gallego 1979) to the northeast.

The study area is the only location in Maine where the truncation of a major high-grade metamorphic terrane is exposed, yet the nature of the boundary fault and the mechanism and timing of emplacement of the Passagassawakeag terrane is poorly understood. Although it has been suggested that such a boundary should exist (Stewart and Wones 1974; Osberg et al. 1985; Kaszuba 1986) previous studies failed to find any field evidence for the existence of the Liberty-Orrington Fault, and some workers suggested that the terrane boundary is an unconformity (McSwiggen 1978; Kaszuba 1986). Recent models have invoked the use of a major thrust fault, either from the northwest or southeast (present coordinates), that was later folded to account for the arcuate map pattern of the terrane boundary (Figs. $1 \& 2$ ) (Stewart et al. 1995; Osberg et al. 1985; 1995; 1998). New mapping shows the existence of a $250-500 \mathrm{~m}$ thick mylonitic shear zone separating the Passagassawakeag terrane and the Fredericton Trough along the trace of the Liberty-Orrington fault in northern Penobscot Bay (Fig. 2). This paper presents the results of a detailed field and petrographic analysis of these fault rocks. 


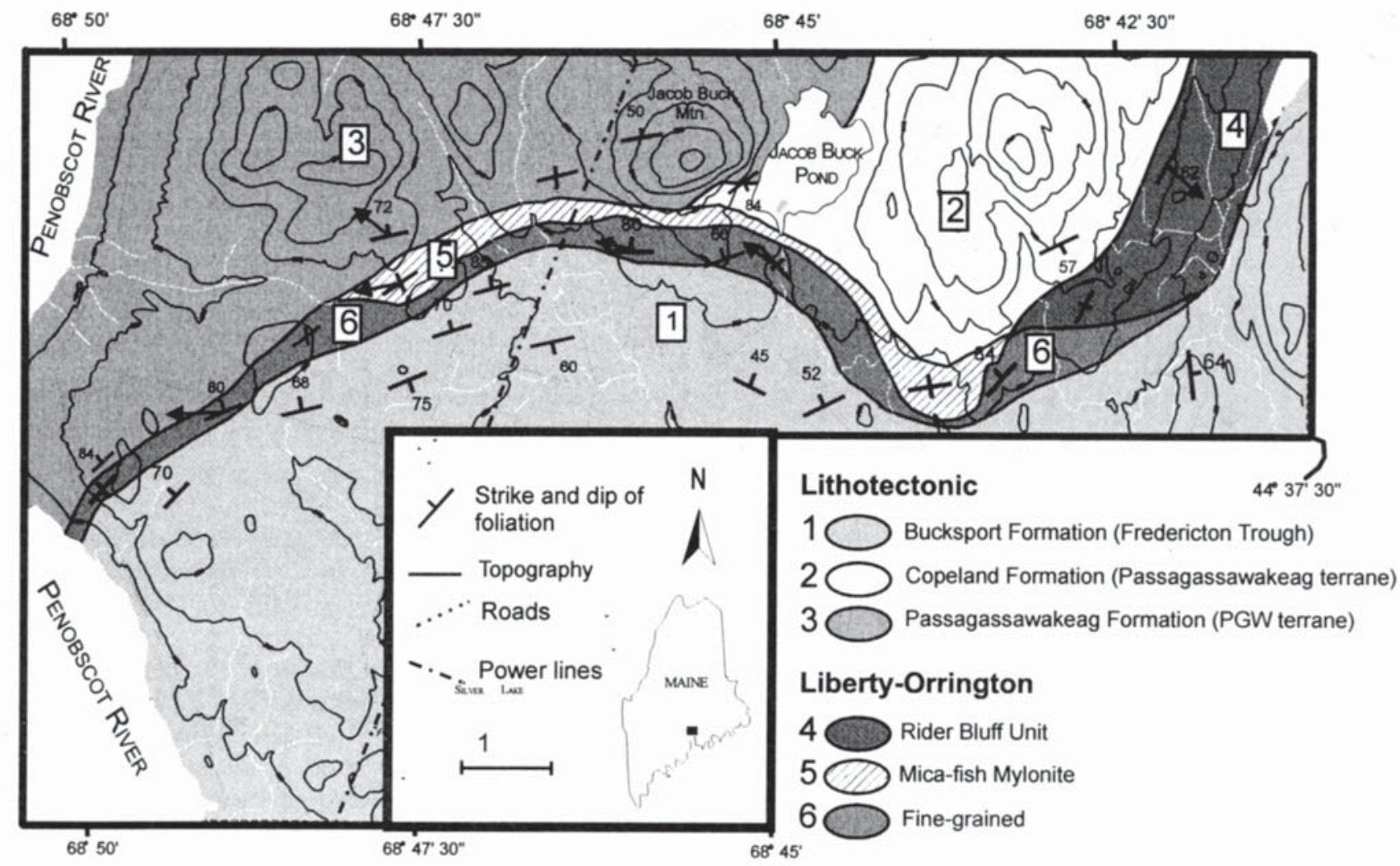

Fig. 2. Geologic map of the Bucksport-Orland area, coastal Maine. PGW = Passagassawakeag terrane.

\section{TERRANE COMPONENTS}

\section{Passagassawakeag terrane}

The Passagassawakeag terrane (Orrington-Liberty Belt of Stewart et al. 1995b; Liberty-Orrington sequence of Osberg et al. 1995) consists of the sillimanite-bearing Passagassawakeag gneiss, schist and quartzite of the Copeland Formation, and the Rider Bluff member (sensu lato) of the Copeland Formation. All are Ordovician or older in age based on Late Silurian (time scale of Harland et al. 1990) or Early Devonian (time scale of Tucker et al. 1998) ages for intraformational migmatites of the Passagassawakeag and Copeland formations $(412 \pm 14 \mathrm{Ma}$, Winterport Granite; $412 \pm 16$ Ma, Stricklen Ridge Granite; Zartman and Gallego 1979). This study focused on the Passagassawakeag gneiss and the Rider Bluff member, where they occur in contact with the surrounding turbidites of the Bucksport Formation.

The Passagassawakeag gneiss is a complexly folded quartz-feldspar-biotite-sillimanite-garnet gneiss with a minor volume of semi-continuous calc-silicate layers that contain diopside-hornblende-plagioclase and pyrophyllite. In the study area, it most often crops out as a grey, pelite-rich layered gneiss with intrusions of the anatectic Stricklen Ridge (412 \pm $16 \mathrm{Ma}$; Zartman and Gallego 1979) garnet-bearing leucogranite, and/or small dikes of the Mt. Waldo Pluton. The abundance of the Stricklen Ridge intrusions increases to the north and east so that the top of Jacob Buck Mountain is almost entirely granite (Fig. 2). The gneiss and granite are also cut by pegmatite dikes, and in some places by small, tourmaline-bearing aplite dikes. In this region of coastal Maine, the Passagassawakeag gneiss is assigned to the high- rank amphibolite facies on the Maine generalized map of regional metamorphic zones (Osberg et al. 1985), and the sillimanite-orthoclase zone by Robinson et al. (1998). It is estimated to have undergone at least two periods of amphibolite-facies metamorphism (West et al. 1995).

On the scale of the orogen, the Passagassawakeag terrane has been correlated with the Casco Bay Belt of Hussey (1988), rocks of the Miramichi terrane of northeastern Maine and New Brunswick (Osberg et al. 1998), high-grade gneisses of southern New England such as the Massabesic gneiss of southeastern New Hampshire and the Putnam-Nashoba terrane (Fig. 1) of eastern Massachusetts and Connecticut (Zen 1983; Keppie 1989; Rankin 1994), and with gneisses of the Gander zone (terrane) of Newfoundland along strike to the northeast (Rankin 1994).

\section{The Fredericton Trough}

In the Bucksport-Orland area, the Fredericton Trough is represented by metaturbidites of the Bucksport Formation, believed to have been deposited in a basin between the Taconic-modified margin of Laurentia and the composite Avalon terrane, on what may have been the last remaining oceanic crust in the area, following closure of the main lapetus Ocean during the Taconic orogeny (Ludman et al. 1993). It has also been suggested that the rocks of the Fredericton Trough were deposited in a deep foreland basin on the Gander margin (of the Central Mobile Belt), contemporaneous with subduction of that margin beneath Laurentia during the Late Silurian (van Staal and de Roo 1995). The Bucksport Formation is devoid of fossils but is cut by Late Silurian and Devonian plutons (Osberg et al. 1985; West et al. 1995), 


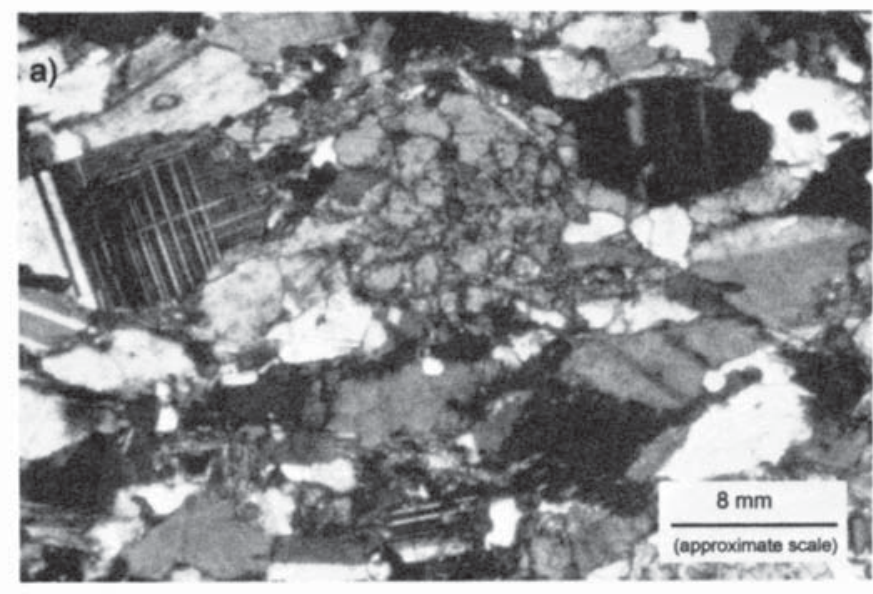

requiring it to be Silurian or older. The Bucksport Formation has been regionally metamorphosed to greenschist facies (chlorite or biotite grade) within the study area and along strike to the northeast. Along strike to the southwest, the Bucksport Formation and equivalent lithological units have undergone up to high grade amphibolite facies regional metamorphism, and have been contact metamorphosed by Devonian plutons (Osberg et al. 1985).

The Bucksport Formation within the Bucksport-Orland area is characterized by greenish-grey beds of pelite and siltstone, $1-10 \mathrm{~cm}$ thick, containing fine-grained quartz, muscovite, biotite, plagioclase, and calcite, with minor amounts of ilmenite, tourmaline, hematite, zircon, and apatite dispersed throughout. It crops out in the far southern and eastern portions of the study area where it is in contact with the Passagassawakeag gneiss and the Rider Bluff unit, respectively. In outcrops within the contact metamorphic aureole of the Mt. Waldo pluton, the Bucksport Formation has a compositional layering, probably hornfelsed transposed bedding, defined by alternating quartz + large biotite and muscovite + hornblende + biotite layers.

\section{Structural GeOlOGy OF TeRrane Rocks}

Proximal to trace of the Liberty-Orrington fault, the Passagassawakeag gneiss exhibits a vertical foliation with a strike of $040^{\circ}$ to $070^{\circ}$ defined by alternating layers of light and dark minerals, and fold axes that are horizontal to nearhorizontal. Stretching lineations in the area are nearhorizontal. The dip of foliation shallows away from the gneiss/turbidite boundary as the pitch of the lineation increases. At a few locations, large Z-folds of the compositional layering occur adjacent to the fault zone. Quartz ribbons, isoclinal folds, and sigmoidal feldspar porphyroclasts are abundant and a dextral sense of shear is consistently indicated. The gneiss lacks well-developed microstructures other than gneissic layering, with only weak S-C fabric present in rocks near the trace of the Liberty-Orrington fault. Quartz occurs as a matrix mineral and in ribbons and veins where it has irregular grain boundaries and undulose extinction, suggesting that it was last deformed in Regime 1 of Hirth and Tullis (1992). Feldspars are recrystallized and grain boundaries are rounded, indicating that the gneiss was previously deformed at high temperatures $\left(\sim 450-500^{\circ} \mathrm{C}\right)$.

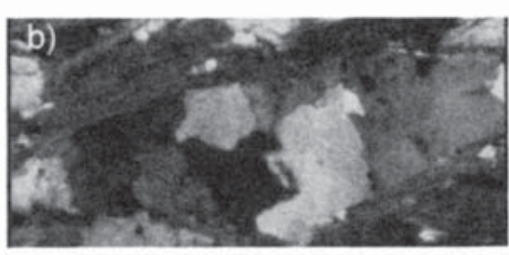

Fig. 3. Photomicrographs of the Passagassawakeag gneiss, polarized light. a) feldspars are rounded due to deformation at high temperatures associated with formation of gneissic banding. b) quartz showing irregular grain boundaries typical of deformation at lower temperatures, probably associated with movement along the LibertyOrrington shear zone.

This deformation is probably associated with gneissic banding and migmatite formation, and the rock has since been deformed at much lower temperatures $\left(\sim 250^{\circ} \mathrm{C}\right)$, as indicated by the quartz textures (Fig. 3).

The least deformed Bucksport Formation within the study area shows a weak foliation defined by small $(\sim 1 \mathrm{~mm}$ thick, discontinuous) zones of aligned micas, with some elongate muscovite. Northeast-trending, steeply plunging fold axes with an axial plane cleavage are common in outcrops at least 560 meters from the Liberty-Orrington fault. Foliation becomes stronger toward the fault, manifested by compositional layering and alignment of micas trending $\sim 25^{\circ}$ to the northwest of layering, with some hornblende- and/or quartz-filled fractures approximately perpendicular to foliation (Fig. 4a). Closer to the Liberty-Orrington fault, the Bucksport has $\mathrm{S}-\mathrm{C}^{\prime}$ fabric $\left(\mathrm{C}^{\prime}\right.$ ' is poorly developed) defined by micas and quartz with undulose extinction, with late quartz- and hornblende-filled fractures oriented in the S-direction $\left(45-60^{\circ}\right.$ E of foliation) (Fig. 4b). In the outcrops adjacent to the contact with the Passagassawakeag terrane where the Bucksport is still distinguishable as such, it is very strained displaying sigmoidal-shaped biotite porphyroclasts, boudinaged quartz ribbons, and an $\mathrm{S}^{-} \mathrm{C}^{\prime}$ foliation that has obliterated the compositional layering, all indicating dextral shear.

\section{THE LIBERTY-ORRINGTON SHEAR ZONE}

The trace of the Liberty-Orrington fault crops out as a continuous band of three distinct types of mylonite: (1) micafish, (2) fine-grained mylonite, both between the Passagassawakeag terrane and the Bucksport Formation along the east-west striking portion of the terrane boundary, and (3) the Rider Bluff unit along the north-south striking part (Fig. 2). The band of mylonite, which varies from 250 to $500 \mathrm{~m}$ in width, is referred to herein as the Liberty-Orrington shear zone. Because of differences in lithology, metamorphic grade, and structure, mylonites along the Liberty-Orrington shear zone are divided here into two groups for ease of discussion: the southern boundary mylonites (easterly striking), and the eastern boundary mylonites (northerly striking; Rider Bluff unit) (Fig. 2). 

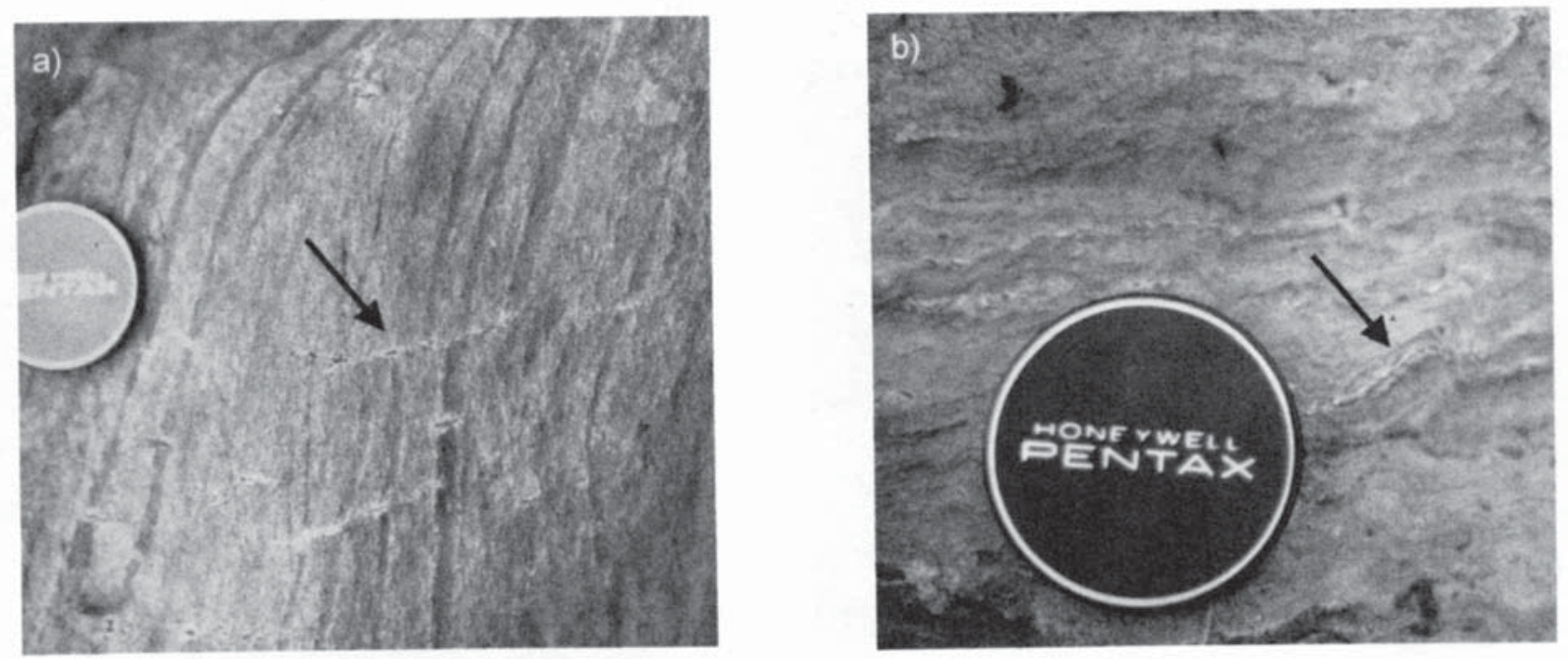

Fig. 4. Field photographs of hornblende-filled fractures in the Bucksport Formation. a) fractures are perpendicular to compositional layering, approximately 250 meters away from the Liberty-Orrington shear zone. b) fractures in Bucksport Formation adjacent to shear zone. Note that they are concordant with foliation and folded in a dextral sense (arrow).

\section{Southern boundary mylonite}

The southern boundary is characterized by two types of mylonite: mica-fish mylonite and fine-grained mylonite. The mica-fish mylonite is generally characterized by an abundance of coarse muscovite porphyroclasts in a largely pelitic matrix. In the vicinity of Jacob Buck Mountain (Fig. 2), the mica fish mylonite occurs as sigmoidal-shaped lenses within finegrained, gray-to-purple mylonite, which is the most abundant type of mylonite in the Liberty-Orrington shear zone. The fine-grained mylonite typically crops out along the southern portion of the shear zone, adjacent to the Bucksport Formation, and is characterized by a sugary texture, commonly with very fine, boudinaged quartz ribbons. Both mylonites contain sillimanite and are therefore thought to originate from the Passagassawakeag gneiss. Dextral S-C fabric is consistently vertical or near-vertical, with the Sdirection (Fig. 5) defined by quartz ribbons and lenses and/or amphiboles, and the C-direction defined by micas. C' foliation is developed in more pelitic samples and layers, and when present, is usually dominant, whereas $\mathrm{C}$ is absent. Nearhorizontal stretching lineations, defined by boudinaged tourmaline, are ubiquitous and consistent with strike-slip motion (Fig. 6). Kinematic indicators include biotite and muscovite mica-fish (Fig. 7a), quartz ribbons, boudinaged quartz veins (Fig. 7b), and delta and sigma-type porphyroclasts of garnet, feldspar + quartz, biotite, and tourmaline (Fig. 7c), all displaying consistent and strong dextral shear. Some samples also have what appear to be garnet fish.

Mylonite within the contact metamorphic aureole of the Mt. Waldo pluton is hornfelsed, as shown by hornblende, biotite, and tourmaline crystals with inclusion-free cores in preferred orientations, and rims that overgrow foliation.

\section{Eastern boundary mylonite - The Rider Bluff unit}

The Rider Bluff unit is unique in that it, and/or a correlative formation, is not known to occur anywhere else in Maine. It is herein referred to as the Rider Bluff unit, as

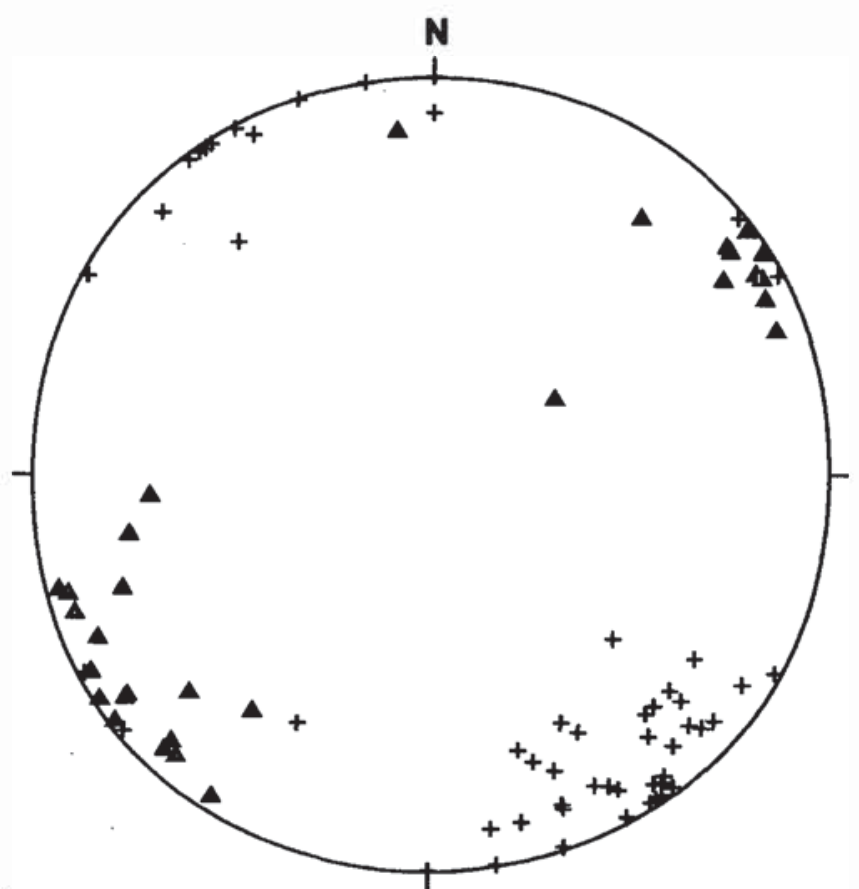

Fig. 5. Equal area projection, lower hemisphere, showing poles to foliation $(+)$ and stretching lineations $(\bullet)$ for southern boundary mylonite of the Liberty-Orrington shear zone.

opposed to a member of the Copeland Formation, for reasons explained below. The fine-grained mylonite of the southern boundary extends to the east as far as Jacob Buck Pond (Fig. 2). The next outcrops to the east are near Bucks Mills, where several distinct fine-grained 'transition' mylonites occur. From here, the Liberty-Orrington fault trace turns sharply northeast and the mylonitic fault rocks are represented by the Rider Bluff unit (formerly a member of the Copeland Formation; Kaszuba and Wones 1985). The general strike of foliation of the Rider Bluff portion of the Liberty-Orrington shear zone is north-northeast with dip near-vertical at the bend and consistently to the east after the boundary turns to the north (Fig. 2). 


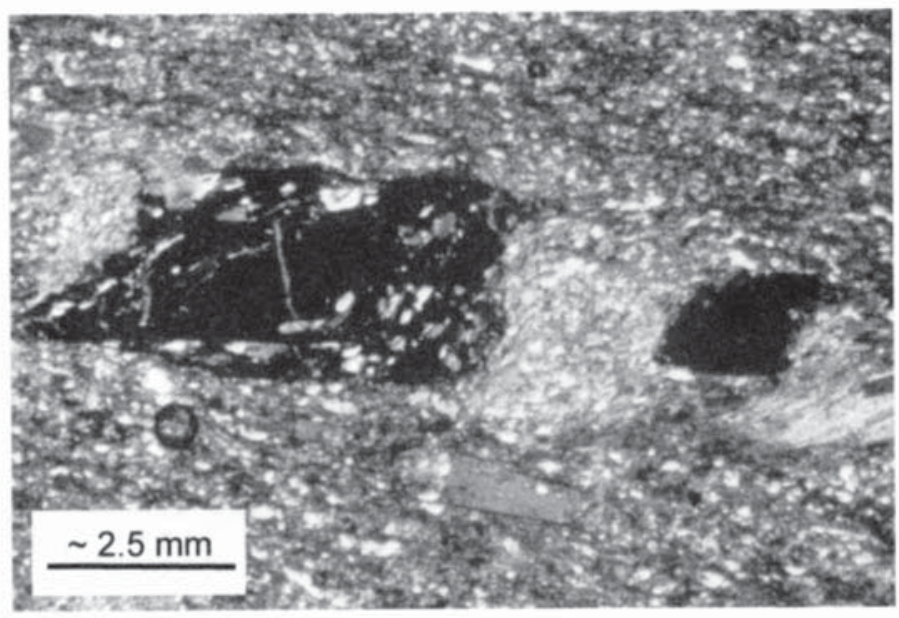

Fig. 6. Photomicrograph of boudinaged tourmaline, defining stretching lineation in southern mylonite, polarized light. Note inclusion-free core oriented in the S-foliation direction.

The Rider Bluff unit has very strong down-dip mineral lineations defined by quartz rods, consistent with a high-angle reverse fault in present orientation. It is fine-grained and finely laminated with consistent $2 \mathrm{~mm}$-thick alternating laminae of quartz + plagioclase and biotite + garnet + magnetite (Fig. 8a), which have previously been interpreted to possibly represent bedding (Kaszuba \& Wones 1985). In thin section quartz is dynamically recrystallized, and displays subgrain development, undulatory extinction and deformation bands oriented approximately perpendicular to compositional banding. These types of structures in quartz are characteristic of deformation Regime 2 of Hirth and Tullis (1992), which implies deformation at approximately $350^{\circ} \mathrm{C}$. In addition, deformation bands in biotite (Fig. 8b), and garnet porphyroclasts indicate that the compositional layering in the Rider Bluff unit defines a foliation and is therefore tectonic, not sedimentary, in origin. It is quite plausible that the Rider Bluff unit is mylonitized Bucksport, Copeland, or some unknown formation and that the entire unit represents a fault zone. Although the present composition of the Rider Bluff may or may not reflect that of the original protolith, it most closely resembles the Bucksport, but is not pelitic enough to be considered part of the formation, and may be derived from a lithology not exposed at the surface (a highly ferrugenous argillite?). The abundance of magnetite and hematite imply that the protolith was iron-rich (possibly of hydrothermal origin), or that the iron was secondarily introduced through solution transfer processes. The Rider Bluff unit is clearly highly strained, so pelitic material and magnetite could have been concentrated in the unit due to circulating fluids during shearing.

Sense of shear indicators for the foliation in the Rider Bluff unit are weak and inconclusive, in part as a consequence of later deformation. However, shear bands with both sinistral and dextral sense occur together (Fig. 8b), implying that a larger component of pure shear than simple shear is responsible for the origin of this unit, which is consistent with mylonite development along a steep thrust. Well-developed
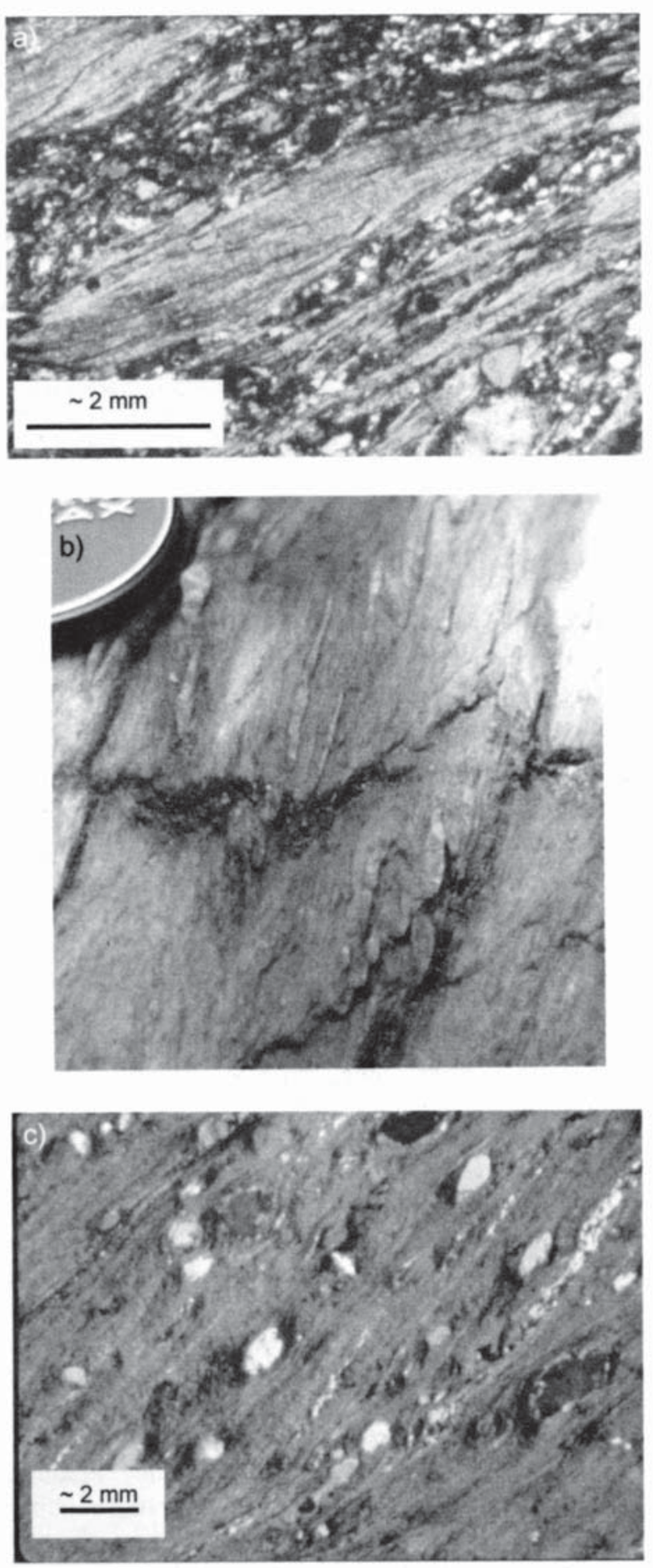

Fig. 7. Kinematic indicators for the southern boundary of the LibertyOrrington shear zone. a) photomicrograph of muscovite mica fish, polarized light. b) field photo of boudinaged quartz ribbons in finegrained mylonite, lens cap for scale. c) photomicrograph of quartz and feldspar porphyroclasts in ultramylonite, with mica matrix. Note quartz ribbon on the right. All kinematic indicators show dextral shear (top/left to the right).

chlorite shear bands with a Bucksport-over-Passagassawakeag shear sense occur in the northern portion of the eastern boundary mylonite where the rocks lie between two splays of the Norumbega Fault Zone.

Biotite porphyroblasts nucleate from and overgrow the primary compositional foliation (Fig. 9), and may have grown 

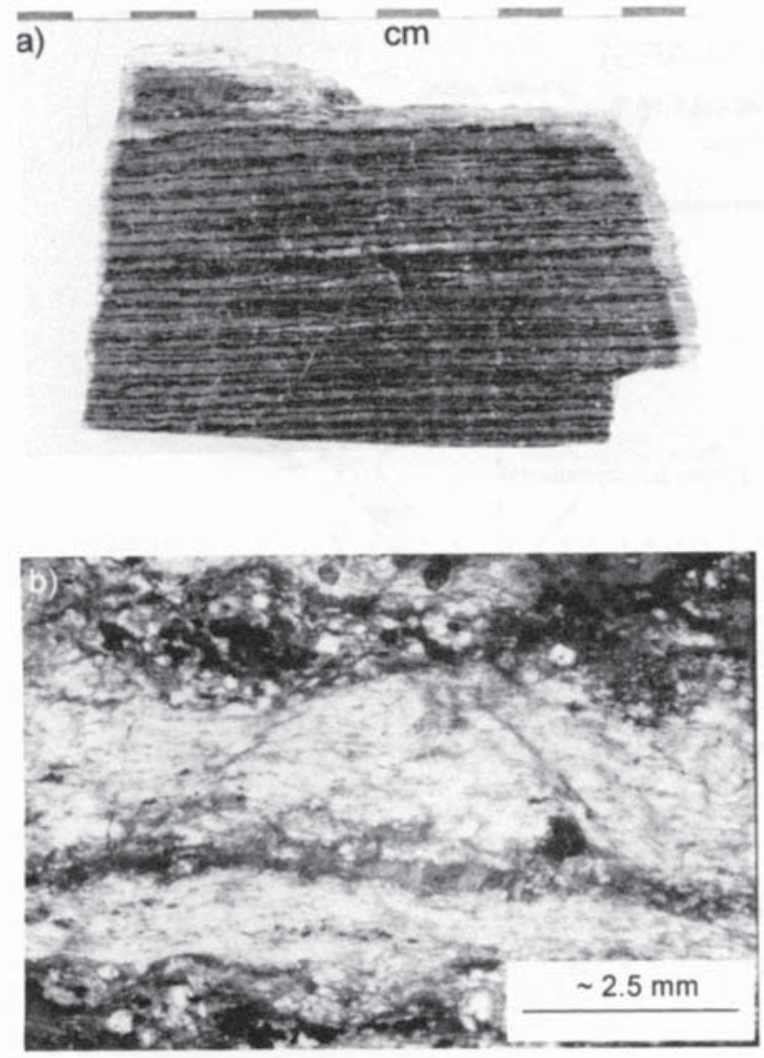

Fig. 8. The Rider Bluff unit, eastern boundary mylonite. a) hand sample showing the $\sim 2 \mathrm{~mm}$ compositional layering characteristic of this unit. Sample cut parallel to down-dip lineations. b) photomicrograph of layering from the same sample as (a), plain light. Note shear bands in both a sinistral (left side) and dextral (right side) sense, indicating pure shear. Also note deformation bands in biotite in thin biotite layer.

in response to the intrusion of the Lucerne pluton, which would make the foliation older than $380 \pm 4 \mathrm{Ma}$ (Bradley et al. 1998). In all mylonites, the metamorphic minerals do not appear to be in equilibrium; retrograde chlorite has partially replaced biotite and garnet, and some plagioclase is altered to sericite. Consequently, a detailed account of prograde metamorphic reactions and their relationship to deformation has not been preserved.

\section{Age Constraints}

At the northern end of Penobscot Bay, the LibertyOrrington shear zone is intruded by the $371 \pm 2 \mathrm{Ma}$ Mt. Waldo pluton (Tucker et al. 1998). Granite dikes clearly have intruded and hornfelsed the Bucksport Formation within the western portion of the study area. Mylonite in the area was hornfelsed as well, as evidenced by the growth of new metamorphic minerals where mylonite lies within the contact metamorphic aureole of the Mt. Waldo granite as well as by the growth of existing minerals over the mylonitic foliation (Fig. 6). The Stricklen Ridge granite is thought to be anatectic, so its $412 \pm 14 \mathrm{Ma}$ age (Zartman and Gallego 1979) may also be the age of the most recent metamorphic event experienced by the Passagassawakeag terrane. Because dikes of the Stricklen Ridge granite/migmatite are involved in mylonitization in the Liberty-Orrington shear zone, this date

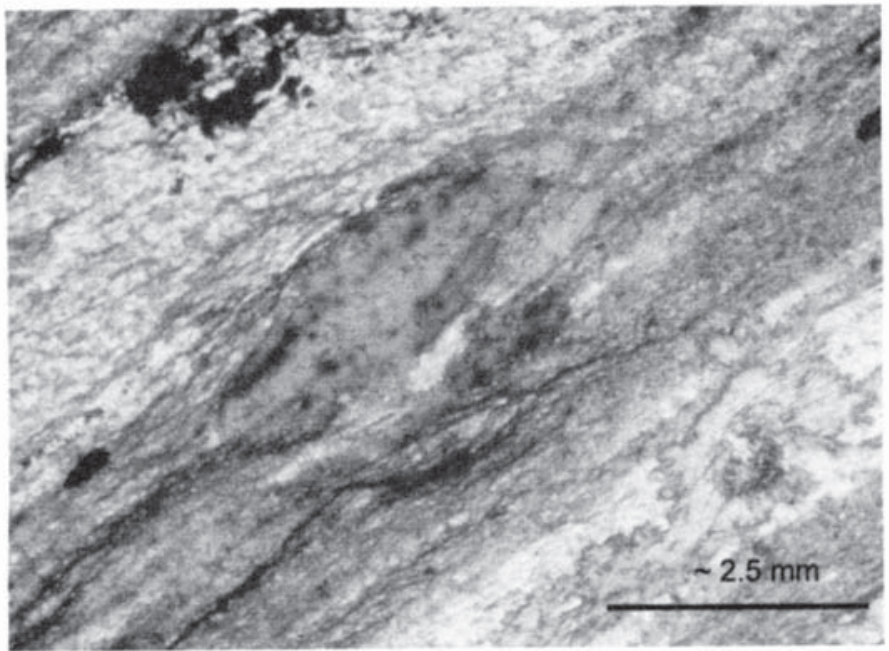

Fig. 9. Photomicrograph of biotite porphyroclast overgrowing foliation in eastern boundary mylonite, plain light. Note compositional layering.

also provides a lower limit on the age of the earliest preserved deformation associated with dextral shearing. Therefore, the Passagassawakeag and Fredericton Trough terranes in the Bucksport-Orland area were juxtaposed close to the beginning of the Acadian orogeny, perhaps even earlier. Movement and mylonite formation began along the southern boundary after $412 \pm 14 \mathrm{Ma}$, and ceased by $371 \pm 2 \mathrm{Ma}$, while mylonitic foliation of the eastern boundary was probably formed near $380 \pm 4 \mathrm{Ma}$, the cooling age for the Lucerne pluton. The timing of intrusion of the Mt. Waldo pluton with respect to the formation of the chlorite shear bands in the Rider Bluff unit is not clear.

Although the most recent sequence of deformation and metamorphism obscures the prograde/burial path through P-T and T-t space (Fig. 10), it provides a record of Devonian movement along the Liberty-Orrington shear zone and consequent exhumation of the Passagassawakeag terrane.

\section{SEQUENCE OF DEFORMATION AND METAMORPHISM}

Ductile dextral shearing began in the early Devonian, sometime after peak metamorphism of the Passagassawakeag gneiss because sillimanite defines the foliation in nonhornfelsed southern boundary mylonites, and the Stricklen Ridge granite is mylonitized (Fig. 10). Mica-fish mylonite is characterized by an abundance of muscovite mica-fish and a paucity of biotite, which may indicate a prolonged deformational event when the mylonites were approximately at $400^{\circ} \mathrm{C}$, the temperature at which biotite is replaced by muscovite through the continuous reaction: garnet + biotite + quartz $+\mathrm{H}_{2} \mathrm{O}=$ chlorite + muscovite (Yardley 1995). If this is the case, then the southern boundary mylonites were at approximately $4.8 \mathrm{kbar}$ and $400^{\circ} \mathrm{C}$, assuming a temperature gradient of $25^{\circ} \mathrm{C}$ per kilometre depth, shortly after peak Acadian metamorphism. The occurrence of two types of mylonite (mica-fish vs. fine-grained) in the Liberty-Orrington shear zone may reflect differences in the $\mathrm{H}_{2} \mathrm{O}$ content of the shear zone rocks, as water is required to drive the above reaction. After formation of the mica-fish mylonite, rocks 


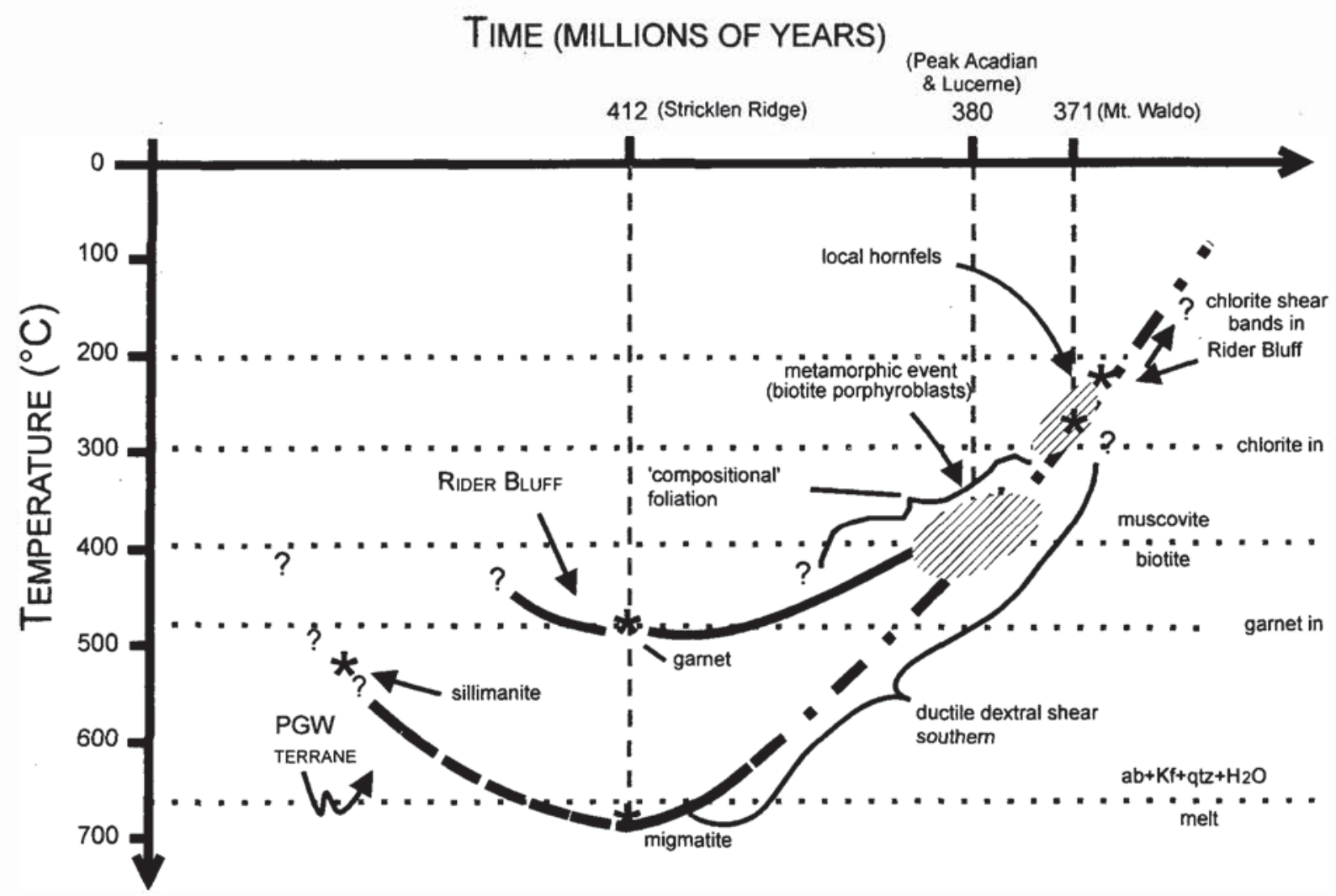

Fig. 10. T-t path for southern and eastern boundary mylonites, and Passagassawakeag terrane. Sample locations are indicated with an $\left({ }^{*}\right)$.

within the western half of the southern boundary were hornfelsed during the intrusion of the $371 \pm 2$ Ma Mt. Waldo pluton (Fig. 10).

The mylonite of the Rider Bluff unit follows a similar T-t path to that described above, except that it may have only reached a maximum pressure and temperature of $\sim 6 \mathrm{kbar}$ and $475^{\circ} \mathrm{C}$, as garnet is the highest grade phase present. Garnet grew sometime in the early (Stricklen Ridge intrusion) to -mid (peak Acadian) Devonian (Fig. 10). The chlorite shear band foliation is the youngest structural and metamorphic feature in the Rider Bluff unit, and is most likely related to later, post (?) -Acadian strike-slip motion along the Norumbega Fault Zone, after movement along the Liberty-Orrington shear zone had ceased. This section of the Rider Bluff unit may have served as a restraining bend between two splays of the NFZ pictured in Fig. 11, along which motion was transferred from one strike-slip fault to the other, forming the chlorite shear band foliation in a Bucksport-over-Passagassawakeag sense. Thrust motion along the restraining bend ceased when the southern splay propagated past the thrust to the northeast, and continued oblique convergence was accommodated by dextral strike-slip movement along the Norumbega Fault Zone (Fig. 11).

\section{TECTONIC EVOLUTION OF THE BUCKSPORT- ORLAND AREA}

Mylonitic foliation within the southern boundary mylonites is vertical with horizontal stretching lineations (Fig. 5), whereas the Rider Bluff unit of the eastern boundary mylonite contains lineations oriented perpendicular to strike of foliation (Fig. 2). Given only this information, it could be argued that the Liberty-Orrington Fault is an elaborately folded pre-metamorphic, pre-Acadian-deformation thrust fault (e.g. Osberg et al. 1995). However, if the eastern boundary is unfolded about a vertical axis so that it is parallel to the strike of the southern boundary, as if it were an extension of it, the orientations of lineations in each boundary mylonite are contradictory, which precludes them having been formed on the same fault in the same manner (Fig. 12). In present orientation, the kinematic indicators in the two boundary mylonites require along-strike transport of the Passagassawakeag terrane from the southwest, during the Devonian. It is unlikely that the dextral shear present in the Liberty-Orrington southern mylonite is an overprinting of earlier thrust motion, as any other direction of transport (e.g. orogen-perpendicular) is not reconcilable with the direction and sense of shear in the eastern mylonite (Rider Bluff unit), which could not have formed through orogen-parallel dextral shear (Fig. 12).

Foliation in the southern mylonites turns north at the 'bend' in the map pattern, and dip of the foliation makes a transition from near-vertical or steeply north-dipping in the southern boundary to vertical at the 'bend', to east-dipping along the eastern boundary, indicating a mechanical continuity between the two boundaries (Fig. 12). Dextral foliation in the mylonite and ultramylonite in the 'bend' is cut by prominent dextral shear bands, implying that they experienced more pure shear than the southern boundary mylonite (Fig. 13). These 'bend' mylonites probably represent a transition from a region of strong dextral shear along the southern boundary to one of thrusting along the eastern boundary. This apparent structural continuity at the bend in the Liberty-Orrington shear zone 

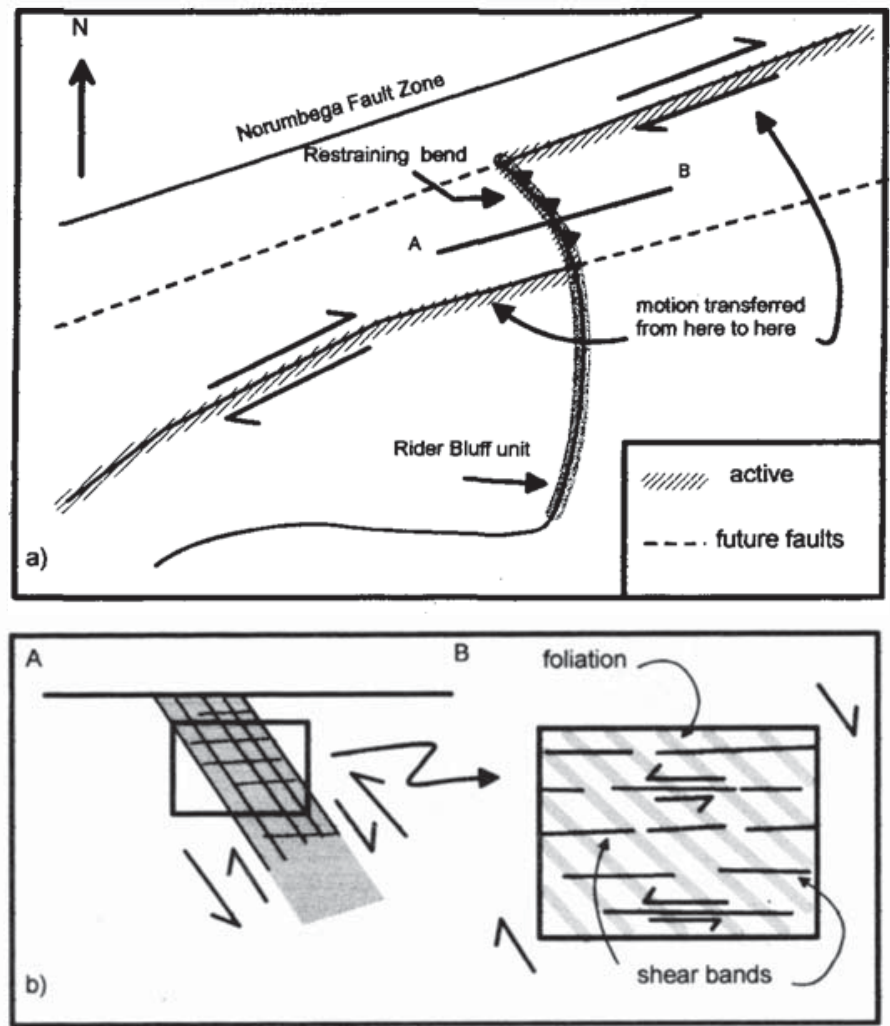

Fig. 11. a) Cartoon of Bucksport-Orland area showing structural conditions under which late chlorite shear bands may have developed, with the northern portion of the Rider Bluff unit as a thrust fault (east over west sense) along a restraining bend between two dextral strike-slip faults of the Norumbega Fault Zone. b) schematic cross-section showing the present orientation of foliation and late chlorite shear bands in the Rider Bluff unit. Gray areas and arrows are foliation: black are for shear bands.

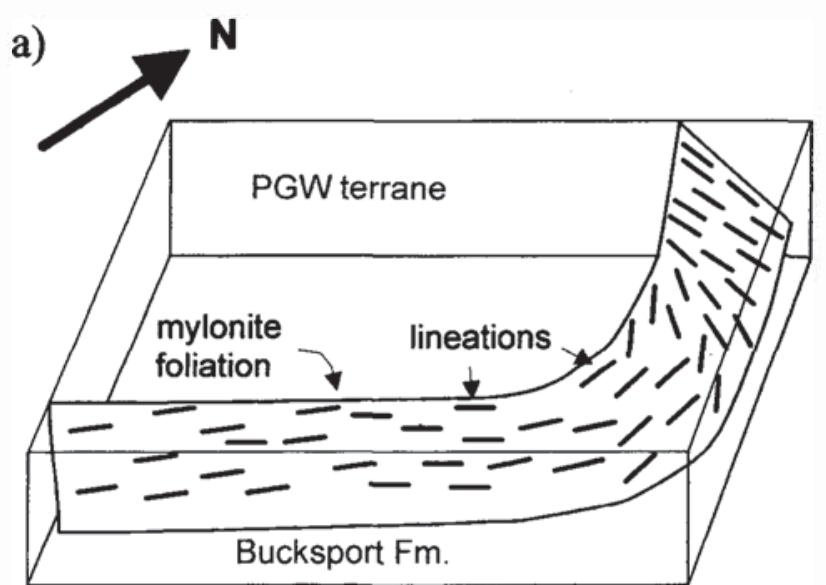

b)

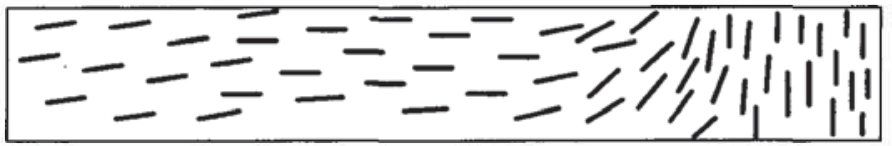

Fig. 12. Schematic diagram showing the mylonitic foliation of the Liberty-Orrington shear zone as one surface, with small black lines representing stretching lineations. a) foliation and lineations in present orientation, shown in three dimensions. $P G W=$ Passagassawakeag. b) cross-sectional view of shear zone after eastern boundary mylonites are 'unfolded' about a vertical axis, as if it were an extension of the southern boundary, formed in the same manner and orientation. Note that the orientations of the lineations present in the mylonites contradict such a model. Therefore, this shear zone cannot represent a folded thrust fault.

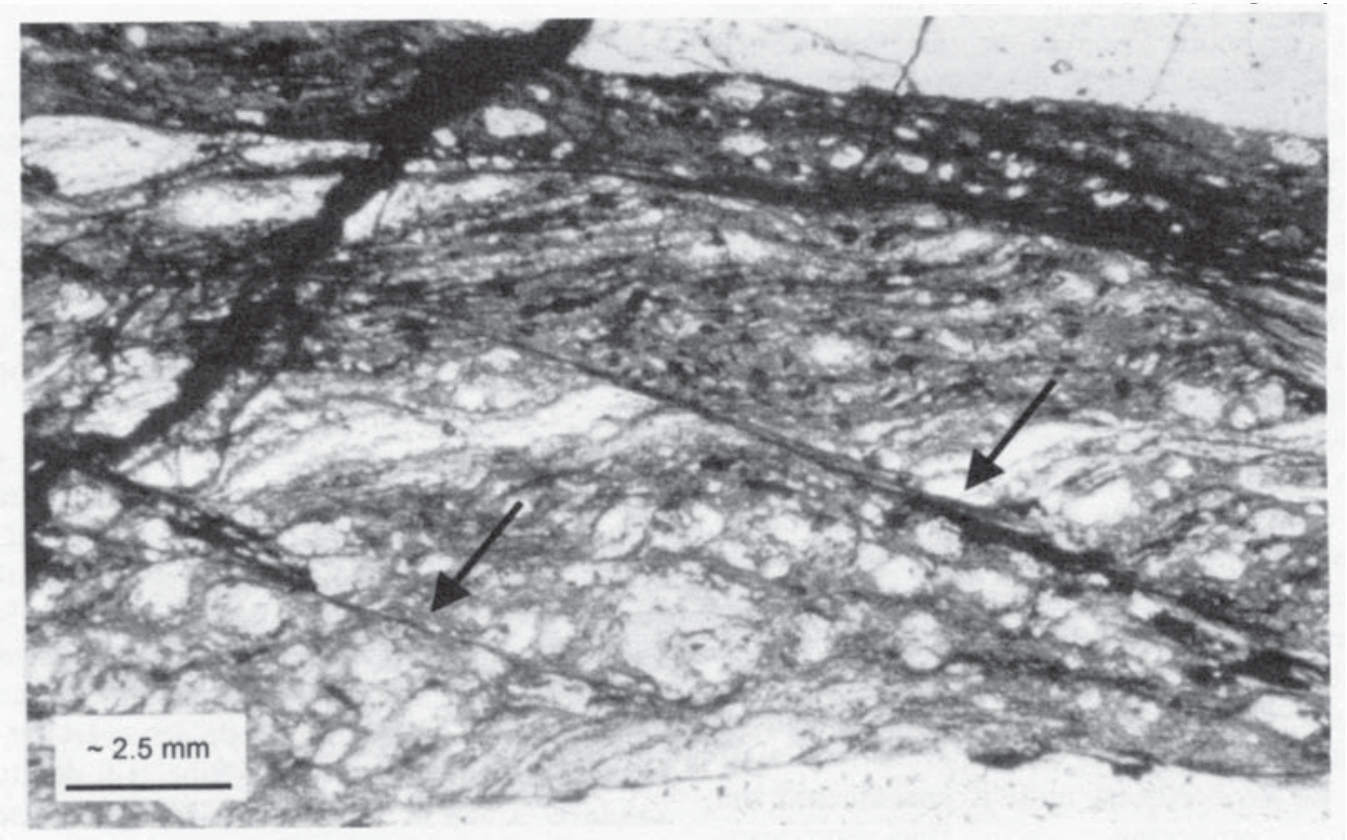

Fig. 13. Photomicrograph of 'bend' mylonite, plain light. Ductile dextral foliation is defined by quartz ribbons, opaques, and porphyroclasts. This foliation is cut by sharp, dextral shear bands (arrows), indicating an element of pure shear. Note ultramylonite at top of photograph. 

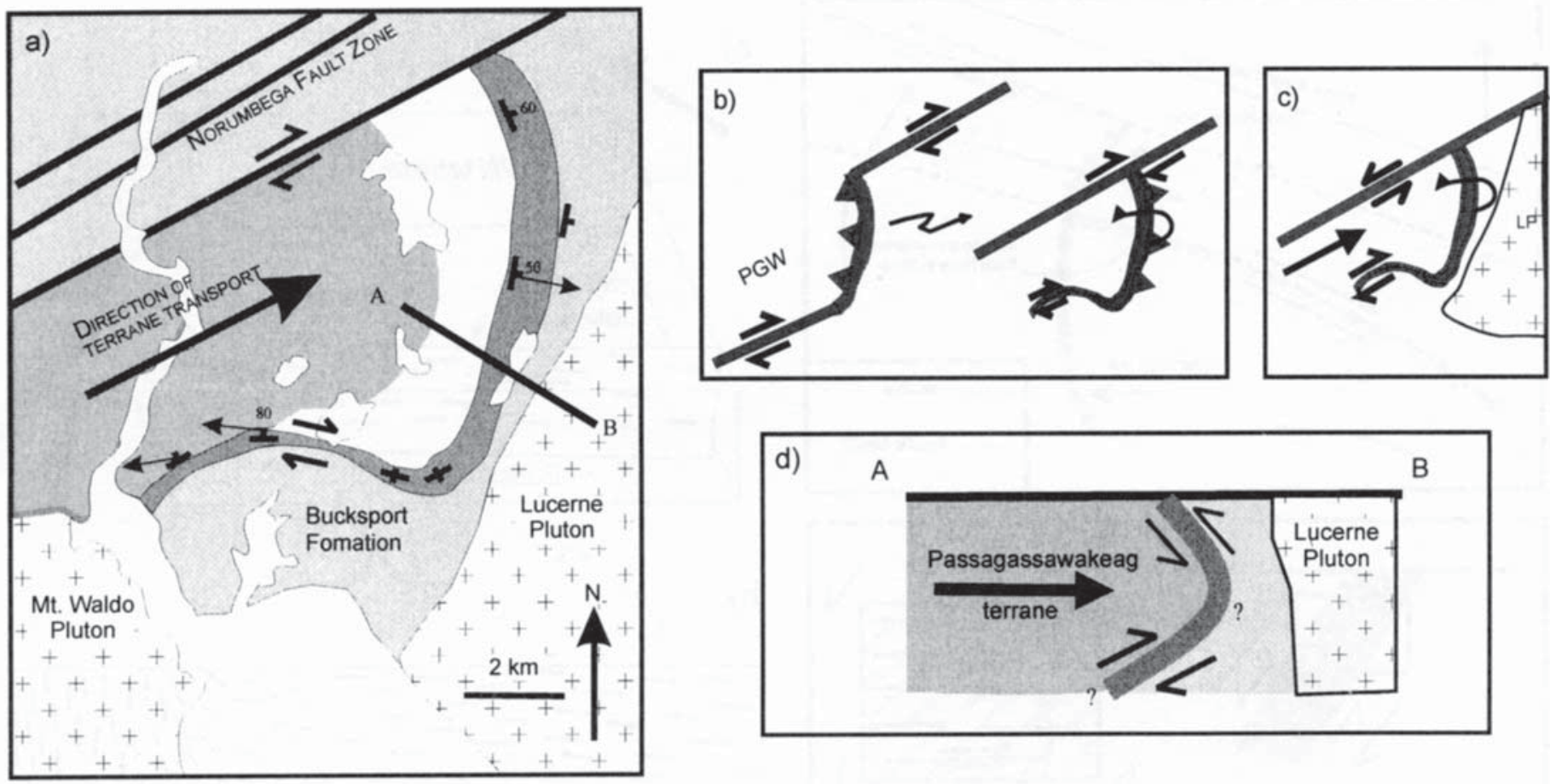

Fig. 14. a) Schematic map and models of the tectonic setting of the exhumation of the Passagassawakeag terrane and overturning of the eastern boundary. b) restraining bend model, map view. c) Lucerne pluton as a barrier model, map view. d) wedge-fault model, cross-section. See text for a full discussion of models.

requires a compatible geometry at depth, with transitional mylonite occurring between the strike-slip and thrust components of the shear zone. The simplest tectonic model that explains the macro and micro structures, outcrop pattern, and kinematic indicators of the Liberty-Orrington shear zone is one in which the southern boundary mylonite represents dextral movement along a strike-slip shear zone, and the eastern boundary mylonite represents an overturned transpressional thrust, along which the Passagassawakeag terrane was exhumed (Figs. $11 \& 14$ ). Several explanations are possible for the present easterly dip of the eastern thrust boundary. The thrust itself may have formed along a restraining bend in the dextral shear system made up of the Liberty-Orrington shear zone and the Norumbega Fault Zone to the northwest, and overturned as a result of the same process that formed the chlorite shear bands in the Rider Bluff unit (Fig. 14b). Another possibility is that the newly formed Lucerne pluton ( $380 \pm 4 \mathrm{Ma}$; Bradley et al. 1998) served as a physical barrier to further orogen-parallel transport of the Passagassawakeag terrane, and the eastern thrust boundary was overturned upon encountering this barrier (Fig. 14c). In a similar scenario, the eastern thrust boundary is not overturned, but forms the upper portion of a wedge fault bounding the Passagassawakeag terrane in cross-section, so that its present orientation is original. In this case, the Passagassawakeag terrane 'plowed' into the surrounding Bucksport formation as it was transported to the northeast until it encountered the Lucerne pluton, producing a Bucksport-overPassagassawakeag thrust sense in the exposed mylonite (Fig. 14d). It is also possible that a combination of any of the above models is responsible for the exhumation of the Passagassawakeag terrane and the present orientation of the Rider Bluff unit of the eastern boundary mylonite. Detailed structural and metamorphic analysis of the Bucksport Formation between the Lucerne pluton and the eastern boundary mylonite is needed to discern which of the above models is most plausible.

\section{THE ROLE OF TRANSPRESSION IN THE ACADIAN OROGENY OF MAINE}

The majority of the tectonic models for the amalgamation of coastal Maine have been focused on the nature of the initial collisions and sutures between terranes, all thought to be major thrust faults (Robinson et al. 1998; Osberg et al. 1995). The Norumbega Fault Zone has long been considered a late, although possibly reactivated, feature with moderate dextral offset that has obscured the original terrane boundary relationships in coastal Maine (Keppie 1989; Osberg et al. 1989; Ludman 1986).

In recent years, extensive, long-lived dextral strike-slip fault systems have been described for coastal Maine (Stewart et al. 1995; Swanson 1995; Hubbard et al. 1995; West and Hubbard 1997). Although many of these fault systems are still considered secondary tectonic features, a Silurian strike-slip fault system in Penobscot Bay is recognized as the primary mechanism of terrane amalgamation, in conjunction with a major thrust fault at depth (Stewart et al. 1995). The Penobscot Bay-Smith Cove-Blue Hill dextral strike-slip fault zone is $3 \mathrm{~km}$ or more wide, and juxtaposes Avalonian and peri-Gondwanan rocks. This fault is believed to be the earliest active fault in the Penobscot Bay region, before $419.5 \pm 1 \mathrm{Ma}$ (U-Pb age of a cross-cutting intrusive suite; Stewart et al. 1995), and dextral movement migrated northwestward (present coordinates) throughout the later part of the Silurian. West and Hubbard (1997) described a wide zone of dextral 
shear along a major splay of the Norumbega Fault Zone to the southwest of Penobscot Bay, interpreted to represent a major episode of Late Devonian (360 Ma) to Early Carboniferous (320 Ma) transpressive tectonism. Dextral strike-slip movement along the Liberty-Orrington shear zone fills both a geographic and temporal gap in the progressive migration of strike-slip motion northwestward (present coordinates) in coastal Maine during the Acadian orogeny, and provides a means for the exhumation of the high-grade Casco BayPassagassawakeag terrane.

\section{CONCLUSIONS}

Because the Passagassawakeag (Liberty-Orrington/Casco Bay) terrane is regionally extensive, the nature of its emplacement into the Bucksport turbidites of the Fredericton Trough has significant implications for the style of amalgamation of the Coastal Lithotectonic Block of Maine and the Acadian orogeny. Abundant evidence for the existence of the Liberty-Orrington fault was found in the form of an extensive and continuous belt of mylonite along its trace. Vertical mylonitic foliation, horizontal stretching lineations, and kinematic indicators within the southern boundary clearly indicate that the Liberty-Orrington fault is a shear zone with right-lateral strike-slip kinematics in its present orientation. The northerly striking Rider Bluff unit mantles the northeastern terminus of the Passagassawakeag terrane, and represents an overturned transpressional thrust along which the terrane was exhumed. The geometry, kinematics, and continuity of the southern and eastern boundary mylonite zones preclude the generation of the entire Liberty-Orrington shear zone as a thrust fault, and requires that it be a part of an orogen-scale dextral shear zone.

Time constraints on the development of the LibertyOrrington shear zone are provided by the cross-cutting late Devonian (371 $\pm 2 \mathrm{Ma})$ Mt. Waldo pluton, and the early Devonian (412 $\pm 14 \mathrm{Ma})$ migmatitic Stricklen Ridge granite, which is deformed by the shear zone. Petrographic analysis reveals a sequence of metamorphic and deformational events through which the exhumation of the Passagassawakeag terrane can be qualitatively traced through P-T and T-t space. The earliest preserved movement within the shear zone occurred sometime in the Early to Middle Devonian, during the Acadian orogeny.

Liberty-Orrington shear zone may represent a part of a more extended continuum of dextral shear in coastal Maine during the early part of the Acadian orogeny, which migrated north with the orogenic wedge (Bradley et al. 1998). The evidence presented in this paper strongly suggests that dextral strike-slip shearing played an integral part in the amalgamation of the terranes in coastal Maine.

\section{ACKNOWLEDGEMENTS}

This research was initiated on the suggestion of Charlie Guidotti, who provided advice throughout the project. The Department of Earth and Atmospheric Sciences at the State University of New York at Albany provided a field vehicle and fuel to facilitate fieldwork. I wish to thank Bill Kidd, Win
Means, Dave Stewart, Doug Reusch, and Riley Brown for many stimulating discussions about mylonites and Maine geology. I would also like to thank Carol Simpson, who read a very early version of this paper, and journal reviewers Les Fyffe and Paul Williams for their critical reviews, which helped clarify many aspects of this paper.

\section{REFERENCES}

BOONE, G.M., \& BOUDETTE, E.L. 1989. Accretion of the Boundary Mountain Terrane within the northern Appalachians orthotectonic zone. In Melanges and olistostromes of the U. S. Appalachians, Edited by J.W. Horton and N. Rast. Geological Society of America, Special Paper 228, pp. 17-42.

BRADLEY, D.C., TUCKER, R.D., LUX, D.R., HARRIS, A.G., \& MCGREGOR, D.C. 1998. Migration of the Acadian Orogen and Foreland Basin across the Northern Appalachians. U.S. Geological Survey, Open-File Report 98-770, p. 79.

HaRland, W.B., ARMSTRONG, R.L., COX, A.V., Craig, L.E., SMITH, A.G., \& SMTTH, D.G. 1990. A geologic time scale, 1989. Cambridge University Press, Cambridge, p. 265.

HIRTH, G. \& TULLIS, J. 1992. Dislocation creep in quartz aggregates. Journal of Structural Geology, 14, pp. 145-159.

HuBbard, M.S., West, D.P. JR., LUdMAN, A., GUIDOTtI, C.V., \& LuX, D.R. 1995. The Norumbega Fault Zone, Maine: a mid- to shallow-level crustal section within a transcurrent shear zone. Atlantic Geology 31, pp. 109-116.

HUSSEY, A.M., II 1988. Lithotectonic stratigraphy, deformation, plutonism, and metamorphism, greater Casco Bay region, southwestern Maine, In Studies in Maine geology. Edited by R.D. Tucker and R.G. Marvinney. Maine Geological Survey, 1, pp. 17-34.

KASZUBA, J.P. 1986. Polyphase deformation and metamorphism in the Penobscot Bay Area, coastal Maine [MS thesis]. Virginia Polytechnic Institute and State University, Blacksburg, VA, 100 p.

KASzUBA, J.P., \& Wones, D.R. 1985. Early Devonian thrusting in the Penobscot Bay area, Maine. Geological Society of America Abstracts with Programs, 17, p. 27.

KEPPIE, J.D. 1989. Northern Appalachian terranes and their accretionary history. Geological Society of America Special Paper 230, pp. 159-192.

LUdMAN, A. 1986. Timing of terrane accretion in eastern and eastcentral Maine. Geology, 14, pp. 411-414.

LUDMAN, A., HOPECK, J.T., \& BROCK, P.C. 1993. Nature of the Acadian orogeny in eastern Maine, in Roy, D.C., and Skehan, J.W., eds., The Acadian Orogeny: Recent Studies in New England, Maritime Canada, and the Autochthnonous Foreland: Boulder, CO, Geological Society of America Special Paper 275, pp. 67-84.

Ludman, A., Hopeck, J.T., \& BRock, P.C. 1993. Nature of the Acadian orogeny in eastern Maine, In The Acadian Orogeny: Recent Studies in New England, Maritime Canada, and the Autochthnonous Foreland. Edited by D.C. Roy and J.W. Skehan. Boulder, CO, Geological Society of America Special Paper 275, pp. 67-84.

MALO, M., \& KIRKWOOD, D. 1995. Faulting and progressive strain history of the Gaspe Peninsula in post-Taconian time: A review. In Current Perspectives in the Appalachian-Caledonian Orogen. Edited by J.P. Hibbard, C.R. van Staal, and P.A. Cawood. Geological Association of Canada, Special Paper 41, pp. 267. 282.

MCSWIGgen, P.L. 1978. Stratigraphy, structural geology and metamorphism of the northeast extension of the LibertyOrrington antiform, south-central Maine [MS thesis]. University 
of Maine, Orono, ME, $127 \mathrm{p}$.

OSBERG, P.H., HuSSEY, A.M., II, \& BoONE, G.M. 1985. Bedrock geologic map of Maine. Maine Geological Survey, scale 1: 500,000 .

OSBERG, P.H., BERRY, H.N., IV, \& TUCKER, R.D. 1998. Acadian tectonics along coastal Maine and southern New Brunswick. Northeastern Geological Society of America Abstracts with Programs, 30, pp. 65.

OSBERG, P.H., TUCKER, R.D., \& BERRY, H.N., IV 1995. Is the Acadian suture lost? In New England Intercollegiate Geological Conference guidebook for field trips in central coastal Maine. Edited by A.M. Hussey II. pp. B2-1 - B2-27.

RANKIN, D.W. 1994. Continental margin of the eastern United States: Past and present, In Phanerozoic Evolution of North American Continent-Ocean Transitions. Edited by R.C. Speed. Boulder, CO, GSA, DNAG Continent-Ocean Transect Volume, pp. 129218.

RoBINSON, P., TUCKER, R.D., BRADley, D., BERRY, H.N., IV, \& OSBERG, P.H. 1998, Paleozoic orogens in New England, USA. GFF v. 120 (Pt. 2, June), p. 119-148.

STEWART, D.B., \& WONES, D.R. 1974. Bedrock geology of northern Penobscot Bay area, In New England Intercollegiate Geological Conference guidebook for field trips in east-central and northcentral Maine. Edited by P.H. Osberg. pp. 233-240.

STEWART, D.B., Unger, J.D., \& HutCHINSON, D.R. 1995a. Silurian tectonic history of Penobscot Bay region, Maine. Atlantic Geology, 31, pp. 67-79.

STEWART, D.B., TUCKER, R.D., \& WEST, D.P., JR. 1995b. Genesis of Silurian composite terrane in northern Penobscot Bay, In New England Intercollegiate Geological Conference guidebook for field trips in central coastal Maine. Edited by A.M. Hussey II, pp. A3-1 - A3-21.
TUCKer, R.D., Bradley, D.C., Ver Straeten, C.A., HaRris, A.G., EBERT, J.R., \& MCCUTCHEON, S.R. 1998. New U-PB zircon ages and the duration and division of Devonian time. Earth and Planetary Science Letters, 158, pp. 175-186.

VAN StaAl, C.R., \& DE ROO, J.A. 1995. Mid-Paleozoic tectonic evolution of the Appalachian Central Mobile Belt in northern New Brunswick, Canada: Collision, extensional collapse, and dextral transpression, In Current Perspectives in the Appalachian-Caledonian Orogen. Edited by J.P. Hibbard, C.R. van Staal, and P.A. Cawood. Geological Association of Canada, Special Paper 41, pp. 367-389.

WEST, D.P., JR., LUDMAN, A., \& LUX, D.R. 1992. Silurian age for the Pocomoonshine gabbro-diorite and its regional tectonic implications. American Journal of Science, 292:4, pp. 253-273.

WeSt, D.P., JR., GuidotTI, C.V., \& LUX, D.R. 1995. Silurian orogenesis in the western Penobscot Bay region, Maine. Canadian Journal of Earth Sciences, 32, pp. 1845-1858.

WEST, D.P., JR., \& HUBBARD, M.S. 1997. Progressive localization of deformation during exhumation of a major strike-slip shear zone: Norumbega fault zone, south-central Maine, USA. Tectonophysics 273, pp. 185-201.

ZaRTMAN, R.E., \& Gallego, M.D. 1979. In Radiometric ages. Edited by R.F. Marvin and S.W. Dobson. Compilation B, U.S. Geological Survey. Isochron West, The Bulletin of Isotope Geochronology, 26, p. 18.

ZEN, E. 1983. Exotic terranes in the New England Appalachianslimits, candidates, and ages: A speculative essay. Geological Society of America Memoir 158, pp. 55-81.

Editorial responsibility: Sandra M. Barr 